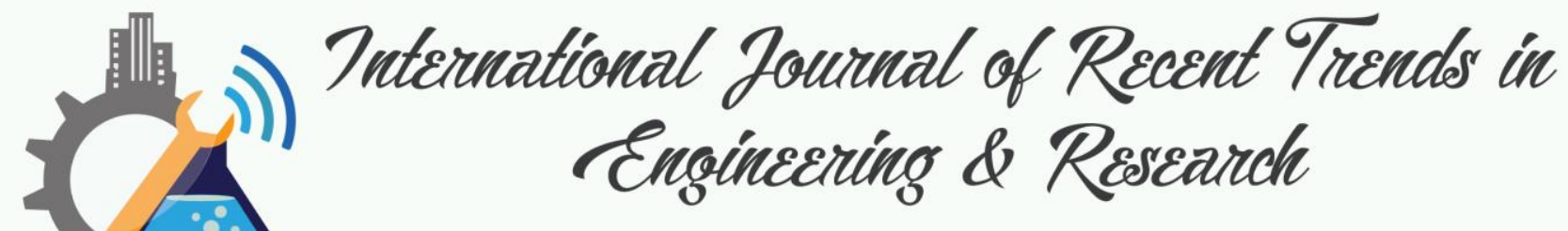

\title{
Best Student Selection Using Extended Promethee II Method
}

\author{
Fadlina $^{1}$, Lince Tomoria Sianturi ${ }^{2}$, Abdul Karim ${ }^{3}$, Mesran $^{4}$, Andysah Putera Utama Siahaan ${ }^{5}$ \\ ${ }^{1,3}$ Department of Informatics Management, AMIK STIEKOM Sumatera Utara, Medan, Indonesia \\ ${ }^{2,4}$ Department of Computer Engineering, STMIK Budi Darma, Medan, Indonesia \\ ${ }^{5}$ Faculty of Computer Science, Universitas Pembanguan Panca Budi, Medan, Indonesia \\ ${ }^{5}$ Ph.D. Student of School Computer Communication Engineering, Universiti Malaysia Perlis, Kangar, \\ Malaysia
}

\begin{abstract}
At the end of learning at an educational level, leaders often perceive difficulties in determining the best students at a certain level of education. Cumulative Achievement Index may not be used for decision makers in determining the best students. There are criteria other criteria that influence them are actively organize, have never done a repair value, never follow short semester, never leave. Using these criteria and using Multi-Criteria Decision Making (MCDM) based methods applied to decision support systems can deliver the expected outcomes of higher education leaders. Many methods can be used on decision support systems such as Promethee, Promethee II, Electre, AHP, SAW, or TOPSIS. In this discussion, the author uses Extended Promethee II method in determining the best student at a college.
\end{abstract}

Keywords:The Best Student, Exprom II, Extended Promethee II

\section{INTRODUCTION}

Students are learners who are actively studying in formal higher education. Students are believed to have a creative mindset in doing every action. In each learning done on the school unit in the form of semester students will get a final grade known as the Semester Achievement Index (IPS). The accumulation of IPS in each semester becomes a Grade Point Average or known as GPA. In one educational unit, it is often difficult for university leaders to determine who is the best student of some students who follow the education process.

Students who have the highest GPA in each semester are not necessarily the best students that can be determined by the leadership of a college. Many factors determine a student to be the best. Among the factors that can determine the best students in addition to GPA is actively organizing, has never done a repair value, never follow the short semester, never leave. The number of criteria to be considered will make the taker more complex in generating a decision. To overcome this, the use of decision support system becomes the main solution that must be met by policy makers [1].

Implementation of information systems-based decision support system capable of processing alternative data along with criteria as a requirement of a leader to easily determine the best student of several alternative students. Decision Support System is a system that can help the user, in this case, the manager or leader, do some specific process to determine the best solution [2]. For example, the determination of the best employees by applying the TOPSIS method can result in more efficient decisions [3]. The application of SPK using Multi-Criteria Decision Making (MCDM) of them can use TOPSIS method, ELECTRE, AHP, PROMETHEE, SAW, WP [4][5][6]. In this case, the implementation of the Extended Promethee II method can be used to determine the best student based on the criteria specified by several alternatives. 


\subsection{Extended Promethee II}

\section{METHODS AND MATERIAL}

The method of Extended Promethee II is the development of Promethee II. Abbreviated with EXPROM II, this method steps resembles with the method of Promethee II. Like its predecessor, this method also uses pairwise comparisons against alternative alternatives taking into account changes in changes to each criterion[7][8].

The steps of The Extended Promethee II(EXPROM2)[8], can be seen below:

\section{Step 1: Normalize the decision matrix}

Normalize the decision matrix $\left(\mathrm{x}_{\mathrm{ij}}\right)$, for the gain attribute using equation 1 and for the cost attribute using equation 2 :

$$
\begin{gathered}
R_{i j}=\left[x_{i j}-\min \left(x_{i j}\right)\right] /\left[\max \left(x_{i j}\right)-\min \left(x_{i j}\right)\right] \ldots \\
\mathrm{i}=1,2, \ldots, \mathrm{m} ; \mathrm{j}=1,2, \ldots, \mathrm{n} \\
R_{i j}=\left[\max \left(x_{i j}\right)-x_{i j}\right] /\left[\max \left(x_{i j}\right)-\min \left(x_{i j}\right)\right] .
\end{gathered}
$$

\section{Step 2: Calculates evaluative differences from alternative $i^{\text {th }}$ with other alternatives.}

This step involves calculating the difference in criterion value $\left(\mathrm{d}_{\mathrm{j}}\right)$ between different alternatives pair-wise.

\section{Step 3: Calculate Preferences $P_{j}\left(i, i^{\prime}\right)$}

There are six main types of preference functions, such as ordinary criteria, U-shape criteria, V-form criteria, level criteria, The V-form criteria and Gaussian criteria, but most are common criteria using the following formula:

$$
\begin{aligned}
& P_{j}\left(i, i^{\prime}\right)=0 \text { if } r_{i j} \leq r_{i^{\prime} j} \\
& P_{j}\left(i, i^{\prime}\right)=\left(r_{i j}-r_{i^{\prime} j}\right) \text { if } r_{i j}>r_{i^{\prime} j}
\end{aligned}
$$

\section{Step 4: Calculate the Weak Preferences Index}

The preference index calculation is weak by considering the weighted value criterion with the following equation.

$$
W P\left(i, i^{\prime}\right)=\left[\sum_{j=1}^{n} W_{j} x P_{j}\left(i, i^{\prime}\right)\right] / \sum_{j=1}^{n} W_{j}
$$

Where $w_{j}$ is the relative importance (weight) of the $\mathrm{j}$ criterion.

\section{Step 5: Define the strict preferences}

The strict preferences, $\operatorname{SPj}\left(i, i^{\prime}\right)$ is based on the ratio of $\mathrm{dmj}$ values to the range of values as defined by the evaluation of all alternative circuits for a criterion.

$$
S P_{j}\left(i, i^{\prime}\right)=\left[\max \left(0, d_{j}-L_{j}\right)\right] /\left[d m_{j}-L_{j}\right]
$$

Where $\mathrm{Lj}$ is the limit of preference ( 0 for the usual criterion preferences function and values unimportant for the other five functions of preference) and dmj differ among other ideal and antiideal values of the number of criteria. 
Step 6: Compute the strict preferences index

The strict preference index calculation uses the following equation:

$$
S P\left(i, i^{\prime}\right)=\left[\sum_{j=1}^{n} W_{j} x S P_{j}\left(i, i^{\prime}\right)\right] / \sum_{j=1}^{n} W_{j}
$$

Step 7: Calculates the value of total preferences index

$$
T P\left(i, i^{\prime}\right)=\operatorname{Min}\left[1, W P\left(i, i^{\prime}\right)+S P\left(i, i^{\prime}\right)\right]
$$

\section{Step 8: Determining leaving flow and entering Outrangking Flow}

Determination of Leaving Flow and Entering Outrangking Flow using the equation:

Leaving (Positive) Flow

$$
\varphi^{+}(i)=\frac{1}{m-1} \sum_{i^{\prime}=1}^{n} T P\left(i, i^{\prime}\right)\left(i \neq i^{\prime}\right)
$$

Entering (Outrangking) Flow.

$$
\varphi^{-}(i)=\frac{1}{m-1} \sum_{i^{\prime}=1}^{n} T P\left(i^{\prime}, i\right)\left(i \neq i^{\prime}\right)
$$

Step 9: Calculating the net outrangking flow

$$
\varphi(i)=\varphi^{+}(i)-\varphi^{-}(i)
$$

\section{Step 10: Determine the rangking}

Determining all the priceless alternatives depends on the value of $\varphi(i)$. The better of alternative is the higher value of $\varphi(i)$.

\section{RESULTS AND DISCUSSION}

Implementation of decision support systems requires alternatives, weights, and criteria in the process of calculation. In table 1 the following criteria have been set:

\section{TABLE I Criteria and Weight}

\begin{tabular}{|l|c|c|}
\hline \multicolumn{1}{|c|}{ Criateria } & Weight & Type \\
\hline IPK (C1) & 0.30 & Benefit \\
\hline Leave Status (C2) & 0.20 & Benefit \\
\hline $\begin{array}{l}\text { Status of Short Repair / Short } \\
\text { Semester (C3) }\end{array}$ & 0.20 & Benefit \\
\hline Active Organizing (C4) & 0.30 & Benefit \\
\hline
\end{tabular}

Table II is the value range of the Leave Status criterion.

Tabel II.The Value of Leave Status (C)
\begin{tabular}{|l|c|}
\hline Information & Value \\
\hline Ever & 50 \\
\hline Never & 100 \\
\hline
\end{tabular}

Table III show the range of values of the Short Values/Short Recovery criteria.

TABLE III Criteria for Improving Value / Short Semester (C3)

\begin{tabular}{|l|c|}
\hline Information & Value \\
\hline Ever & 50 \\
\hline Never & 100 \\
\hline
\end{tabular}


Table IV is a range of values from Active Organizing criteria.

TABLE IVActive Organizing (C4)
\begin{tabular}{|l|c|}
\hline Information & Value \\
\hline Inactive & 0 \\
\hline Less Active & 50 \\
\hline Active & 100 \\
\hline
\end{tabular}

Table V, is a list of student alternatives to be selected the best.

TABLE V Student Alternative

\begin{tabular}{|c|c|c|c|c|}
\hline \multirow{2}{*}{ Alternative } & \multicolumn{4}{|c|}{ Criteria } \\
\cline { 2 - 5 } & $\mathrm{C} 1$ & $\mathrm{C} 2$ & $\mathrm{C} 3$ & $\mathrm{C} 4$ \\
\hline $\mathrm{A}_{1}$ & 3.80 & Never & Never & Active \\
\hline $\mathrm{A}_{2}$ & 3.80 & Ever & Ever & Inactive \\
\hline $\mathrm{A}_{3}$ & 3.75 & Never & Never & Active \\
\hline $\mathrm{A}_{4}$ & 3.90 & Never & Ever & $\begin{array}{c}\text { Less } \\
\text { Active }\end{array}$ \\
\hline
\end{tabular}

Based on table $\mathrm{V}$ and the range of values on each criterion, the results of each alternative are obtained as follows:

TABLE VII The alternative Match Rating Table and Criteria

\begin{tabular}{|c|c|c|c|c|}
\hline \multirow{2}{*}{ Alternative } & \multicolumn{4}{|c|}{ Criteria } \\
\cline { 2 - 5 } & $\mathrm{C} 1$ & $\mathrm{C} 2$ & $\mathrm{C} 3$ & $\mathrm{C} 4$ \\
\hline $\mathrm{A}_{1}$ & 3.80 & 100 & 100 & 100 \\
\hline $\mathrm{A}_{2}$ & 3.80 & 50 & 100 & 0 \\
\hline $\mathrm{A}_{3}$ & 3.75 & 100 & 100 & 100 \\
\hline $\mathrm{A}_{4}$ & 3.90 & 100 & 50 & 50 \\
\hline
\end{tabular}

The first step is to apply the EXPROM II method, which is normalizing the decision matrix using equation 1.

$$
\begin{aligned}
& \mathrm{C} 1=\mathrm{IPK} \\
& R 1,1=\frac{[3.80-3.75]}{[3.90-3.75]}=0.333333 \\
& R 2,1=\frac{[3.80-3.75]}{[3.90-3.75]}=0.333333 \\
& R 3,1=\frac{[3.75-3.75]}{[3.90-3.75]}=0 \\
& R 3,1=\frac{[3.90-3.75]}{[3.90-3.75]}=1 \\
& \mathrm{C} 2=\text { Leave Status } \\
& R 1,2=\frac{[100-50]}{[100-50]}=1 \\
& R 2,2=\frac{[50-50]}{[100-50]}=0
\end{aligned}
$$


$R 3,2=\frac{[100-50]}{[100-50]}=1$

$R 3,2=\frac{[100-5]}{[100-50]}=1$

Do the same for $\mathrm{C} 3$ and $\mathrm{C} 4$ so the result will be seen in Table VIII.

TABLE VIII The Normalize Matrix

\begin{tabular}{|c|c|c|c|c|}
\hline Alternative & $\mathrm{C} 1$ & $\mathrm{C} 2$ & $\mathrm{C} 3$ & $\mathrm{C} 4$ \\
\hline $\mathrm{A}_{1}$ & 0.333333 & 1 & 1 & 1 \\
\hline $\mathrm{A}_{2}$ & 0.333333 & 0 & 1 & 0 \\
\hline $\mathrm{A}_{3}$ & 0 & 1 & 1 & 1 \\
\hline $\mathrm{A}_{4}$ & 1 & 1 & 0 & 0.5 \\
\hline
\end{tabular}

The next step is finding for the Preferences $P_{j}\left(i, i^{\prime}\right)$ with equations 3 and 4.

For $\mathrm{C} 1$, pairs-wise matrix:

if $0.333333 \leq 0,333333$ True, then $P_{1}(1,2)=0$

if $0.333333 \leq 0$ False Else if $0.333333>0$ True, then $P_{1}(1,3)=0.333333-0$ $=0.333333$

if $0.333333 \leq 1$ True, then $P_{1}(1,4)=0$

if $0.333333 \leq 0.333333$ True, then $P_{1}(2,1)=0$

if $0.333333 \leq 0$ False Else if $0.333333>0$ True, then $P_{1}(2,3)=0.333333-0=0.333333$

if $0.333333 \leq 1$ True, then $P_{1}(2,4)=0$

if $0 \leq 0.333333$ True, then $P_{1}(3,1)=0$

if $0 \leq 0.333333$ True, then $P_{1}(3,2)=0$

if $0 \leq 0.333333$ True, then $P_{1}(3,4)=0$

if $1 \leq 0.33333310$ False Else if $1>0.333333$ True, then $P_{1}(4,1)=1-0.333333$

$$
=0.666667
$$

if $1 \leq 0.33333310$ False Else if $1>0.333333$ True, then $P_{1}(4,2)=1-0.333333$

$$
=0.666667
$$

if $1 \leq 0$ False Else if $1>0$ True, then $P_{1}(4,3)=1-0=1$

For $\mathrm{C} 2$, the matrix pairs:

if $1 \leq 0$ False Else if $1>0$ True, then $P_{2}(1,2)=1-0=1$

if $1 \leq 1$ True, then $P_{2}(1,4)=0$

if $1 \leq 1$ True, then $P_{2}(1,3)=0$

if $0 \leq 1$ True, then $P_{2}(2,1)=0$

if $0 \leq 1$ True, then $P_{2}(2,3)=0$

if $0 \leq 1$ True, then $P_{2}(2,4)=0$

if $1 \leq 1$ True, then $P_{2}(3,1)=0$

if $1 \leq 0$ False Else if $1>0$ True, then $P_{2}(3,2)=1-0=1$

if $1 \leq 1$ True, then $P_{2}(4,1)=0$

if $1 \leq 0$ False Else if $1>0$ True, then $P_{2}(4,2)=1-0=1$

if $1 \leq 1$ True, then $P_{2}(4,3)=0$

Next, do the same steps for $\mathrm{C} 3$ and $\mathrm{C} 4$, will get the results as in table IX. 
TABLE IX Result of comparison of matrix pairs-wise

\begin{tabular}{|c|c|c|c|c|}
\hline Alternative & C1 & C2 & C3 & C4 \\
\hline $\mathrm{P}_{1}(1,2)$ & 0 & 1 & 0 & 1 \\
\hline $\mathrm{P}_{1}(1,3)$ & 0.333333 & 0 & 0 & 0 \\
\hline $\mathrm{P}_{1}(1,4)$ & 0 & 0 & 1 & 0.5 \\
\hline $\mathrm{P}_{2}(2,1)$ & 0 & 0 & 0 & 0 \\
\hline $\mathrm{P}_{2}(2,3)$ & 0.333333 & 0 & 0 & 0 \\
\hline $\mathrm{P}_{2}(2,4)$ & 0 & 0 & 1 & 0 \\
\hline $\mathrm{P}_{3}(3,1)$ & 0 & 0 & 0 & 0 \\
\hline $\mathrm{P}_{3}(3,2)$ & 0 & 1 & 0 & 1 \\
\hline $\mathrm{P}_{3}(3,4)$ & 0 & 0 & 1 & 0.5 \\
\hline $\mathrm{P}_{4}(4,1)$ & 0.666667 & 0 & 0 & 0 \\
\hline $\mathrm{P}_{4}(4,2)$ & 0.666667 & 1 & 0 & 0.5 \\
\hline $\mathrm{P}_{4}(4,3)$ & 1 & 0 & 0 & 0 \\
\hline
\end{tabular}

The next process calculates the Weak Preferential Value using equation 5.

$\mathrm{WP}(1,2)=((0.3 * 0)+(0.2 * 1)+(0.2 * 0)+(0.3 * 1)) / 1=0.5$

$\mathrm{WP}(1,3)=((0.3 * 0.333333)+(0.2 * 0)+(0.2 * 0)+(0.3 * 0)) / 1=0.1$

$\mathrm{WP}(1,4)=((0.3 * 0)+(0.2 * 0)+(0.2 * 1)+(0.3 * 0.5)) / 1=0.5$

$\mathrm{WP}(2,1)=((0.3 * 0)+(0.2 * 0)+(0.2 * 0)+(0.3 * 0)) / 1=0$

Calculate up to $\mathrm{P}_{4}$ (4.3), and the results obtained as in Table

TABLE $\boldsymbol{X}$ Weak Preference
\begin{tabular}{|c|c|}
\hline Alternative & Value \\
\hline WP $(1,2)$ & 0.5 \\
\hline WP $(1,3)$ & 0.1 \\
\hline WP $(1,4)$ & 0.35 \\
\hline WP $(2,1)$ & 0 \\
\hline WP $(2,3)$ & 0.1 \\
\hline WP $(2,4)$ & 0.2 \\
\hline WP $(3,1)$ & 0 \\
\hline WP $(3,2)$ & 0.5 \\
\hline WP $(3,4)$ & 0.35 \\
\hline WP $(4,1)$ & 0.2 \\
\hline WP $(4,2)$ & 0.55 \\
\hline WP $(4,3)$ & 0.3 \\
\hline
\end{tabular}

Then use equation 6 to find the value of strictpreference, the result as in Table XI

TABLE XI Strict Preferences
\begin{tabular}{|c|c|}
\hline Alternative & Value \\
\hline SP $(1,2)$ & 0.5 \\
\hline SP $(1,3)$ & 0.1 \\
\hline SP $(1,4)$ & 0.35 \\
\hline SP $(2,1)$ & 0 \\
\hline SP $(2,3)$ & 0.1 \\
\hline SP $(2,4)$ & 0.2 \\
\hline
\end{tabular}




\begin{tabular}{|c|c|}
\hline Alternative & Value \\
\hline $\mathrm{SP}(3,1)$ & 0 \\
\hline $\mathrm{SP}(3,2)$ & 0.5 \\
\hline $\mathrm{SP}(3,4)$ & 0.35 \\
\hline $\mathrm{SP}(4,1)$ & 0.2 \\
\hline $\mathrm{SP}(4,2)$ & 0.55 \\
\hline $\mathrm{SP}(4,3)$ & 0.3 \\
\hline
\end{tabular}

From WP and SP, calculate the Total Preference value by using an equation to 8 .

TABLE XII The Total Preference Value

\begin{tabular}{|c|c|}
\hline Alternative & Value \\
\hline $\mathrm{TP}(1,2)$ & $\operatorname{Min}[1,0.5+0.5]=1$ \\
\hline $\mathrm{TP}(1,3)$ & $\begin{array}{c}\operatorname{Min}[1,0.1+0.1]= \\
0.2\end{array}$ \\
\hline $\mathrm{TP}(1,4)$ & $\begin{array}{c}\operatorname{Min}[1,0.35+0.35]= \\
0.7\end{array}$ \\
\hline $\mathrm{TP}(2,1)$ & $\operatorname{Min}[1,0+0]=0$ \\
\hline $\mathrm{TP}(2,3)$ & $\begin{array}{c}\operatorname{Min}[1,0.1+0.1]= \\
0.2\end{array}$ \\
\hline $\mathrm{TP}($ & $\begin{array}{c}\operatorname{Min}[1,0.2+0.2]= \\
0.4\end{array}$ \\
\hline $\mathrm{TP}(3,1)$ & $\operatorname{Min}[1,0+0]=0$ \\
\hline $\mathrm{TP}(3,2)$ & $\operatorname{Min}[1,0.5+0.5]=1$ \\
\hline $\mathrm{TP}(3,4)$ & $\begin{array}{c}\operatorname{Min}[1,0.35+0.35]= \\
0.7\end{array}$ \\
\hline $\mathrm{TP}(4,1)$ & $\begin{array}{c}\operatorname{Min}[1,0.2+0.2]= \\
0.4\end{array}$ \\
\hline $\mathrm{TP}(4,2)$ & $\begin{array}{c}\operatorname{Min}[1,0.55+0.55]= \\
1\end{array}$ \\
\hline $\mathrm{TP}(4,3)$ & $\begin{array}{c}\operatorname{Min}[1,0.3+0.3]= \\
0.6\end{array}$ \\
\hline
\end{tabular}

From Table XII will form the dominant aggregate matrix as follows:

$$
\left[\begin{array}{cccc}
- & 1 & 0.2 & 0.7 \\
0 & - & 0.2 & 0.4 \\
0 & 1 & - & 0.7 \\
0.4 & 1 & 0.3 & -
\end{array}\right]
$$

The next step calculate Leaving Flow and Entering (Outrangking) Flow using equations 9 and 10.

$$
\begin{aligned}
\varphi 1^{+} & =\frac{1}{4-1}[1+0.2+0.7]=\frac{1}{3} \times 1.9=0.63333 \\
\varphi 2^{+} & =\frac{1}{4-1}[0+0.2+0.4]=\frac{1}{3} x 0.6=0.2 \\
\varphi 3^{+} & =\frac{1}{4-1}[0+1+0.7]=\frac{1}{3} x 1.7=0.56667 \\
\varphi 4^{+} & =\frac{1}{4-1}[0.4+1+0.3]=\frac{1}{3} x 1.7=0.66667
\end{aligned}
$$


$\varphi 1^{-}=\frac{1}{4-1}[0+0+0.4]=\frac{1}{3} x 0.4=0,13333$

$\varphi 2^{-}=\frac{1}{4-1}[1+1+1]=\frac{1}{3} \times 3=1$

$\varphi 3^{-}=\frac{1}{4-1}[0.2+0.2+0.6]=\frac{1}{3} x 1=0,33333$

$\varphi 4^{-}=\frac{1}{4-1}[0.7+0.4+0.7]=\frac{1}{3} x 1.8=0,6$

The last step calculates the Net (Outrangking) Flow using equation 11.

TABLE XIII The Leaving Flow and Entering Flow

\begin{tabular}{|c|c|c|c|}
\hline $\begin{array}{c}\text { Alternativ } \\
\mathrm{e}\end{array}$ & $\begin{array}{c}\text { Leaving } \\
\text { Flow }\end{array}$ & $\begin{array}{c}\text { Entering } \\
\text { (Outrangki } \\
\text { ng) Flow }\end{array}$ & $\begin{array}{c}\text { Net } \\
\text { (Outrangkin } \\
\text { g) Flow }\end{array}$ \\
\hline $\mathrm{A}_{1}$ & 0.63333 & 0.13333 & 0.500 \\
\hline $\mathrm{A}_{2}$ & 0.2 & 1 & -0.800 \\
\hline $\mathrm{A}_{3}$ & 0.56667 & 0.33333 & 0.233 \\
\hline $\mathrm{A}_{4}$ & 0.66667 & 0.6 & 0.067 \\
\hline
\end{tabular}

TABLE XIV Rangking

\begin{tabular}{|c|c|c|}
\hline Alternative & Result & Rank \\
\hline $\mathrm{A}_{1}$ & 0.500 & 1 \\
\hline $\mathrm{A}_{2}$ & -0.800 & 4 \\
\hline $\mathrm{A}_{3}$ & 0.233 & 2 \\
\hline $\mathrm{A}_{4}$ & 0.067 & 3 \\
\hline
\end{tabular}

From the calculation, it is clear that Alternative $A_{1}$ is the best alternative of all alternatives.

\section{CONCLUSION}

In this paper, the author explores the use of Extended Promethee II method in solving the problem of determining the best students and generate more efficient decisions. The effectiveness of the resulting decisions can motivate students to be more active in learning. In this paper, four criteria in the determination and policy makers can add other criteria such as certificates either from the study organizers, student achievement.

\section{REFERENCES}

[1] S. Kusumadewi, S. Hartati, A. Harjoko, and R. Wardoyo, Fuzzy Multi-Attribute Decision Making (Fuzzy MADM). Yogyakarta: Graha Ilmu, 2006.

[2] Risawandi and R. Rahim, "Study of the Simple Multi-Attribute Rating Technique For Decision Support," IJSRST, vol. 2, no. 6, pp. 491-494, 2016.

[3] Jasri, D. Siregar, and R. Rahim, "Decision Support System Best Employee Assessments with Technique for Order of Preference by Similarity to Ideal Solution," Int. J. Recent TRENDS Eng. Res., vol. 3, no. 3, pp. 6-17, 2017.

[4] Mesran, G. Ginting, Suginam, and R. Rahim, "Implementation of Elimination and Choice Expressing Reality ( ELECTRE) Method in Selecting the Best Lecturer ( Case Study STMIK BUDI DARMA )," Int. J. Eng. Res. Technol. (IJERT, vol. 6, no. 2, pp. 141-144, 2017.

[5] M. Iswan, W. Fitriani, N. Mayasari, and A. P. U. Siahaan, "Tuition Reduction Determination Using Fuzzy Tsukamoto," Int. J. Eng. Sci. Invent., vol. 5, no. 9, pp. 68-72, 2016.

[6] A. V. Manikrao and C. Shankar, "Facility Location Selection using PROMETHEE II Method," Int. Conf. Ind. Eng. Oper. Manag. Dhaka, pp. 59-64, 2010.

[7] W. Bengal, W. Bengal, and W. Bengal, "A comparative study of preference dominance-based approaches for selection of industrial robots," Adv. Prod. Eng. Manag., vol. 9, no. 1, pp. 5-20, 2014.

[8] P. Chatterjee and S. Chakraborty, "Flexible manufacturing system selection using preference ranking methods: A comparative study," Int. J. Ind. Eng. Comput., vol. 5, no. 2, pp. 315-338, 2014. 
International Journal of Recent Trends in Engineering \& Research (IJRTER) Volume 03, Issue 08; August - 2017 [ISSN: 2455-1457]

[9] H. Zhao, Y. Peng, and W. Li, "Revised PROMETHEE II for improving efficiency in emergency response," Procedia Comput. Sci., vol. 17, pp. 181-188, 2013.

[10] C.-L. Yoon, K.P., \& Hwang, "Multiple Attribute Decision Making: An Introduction,” Sage Univ. Pap. Ser. Quantative Appl. Soc. Sci., pp. 47-53, 1995. 